\title{
Effect of Zinc Addition on Void Formation in Solid-Liquid Interdiffusion Bonding of Copper
}

\author{
S. Fukumoto ${ }^{1}$, T. Miyazaki ${ }^{2}$, M. Matsushima ${ }^{1}$ and K. Fujimoto ${ }^{1}$ \\ ${ }^{1}$ Graduate School of Engineering, Osaka University, 2-1 Yamadaoka, Suita, Osaka 565-0871, Japan \\ ${ }^{2}$ Graduate Student of Osaka University, 2-1 Yamadaoka, Suita, Osaka 565-0871, Japan
}

\begin{abstract}
Solid-liquid interdiffusion bonding of $\mathrm{Cu}$ was carried out at $573 \mathrm{~K}$ with deposited $\mathrm{Sn}$ and $\mathrm{Cu}$ films. The effect of $\mathrm{Zn}$ addition to the faying surfaces was investigated to reduce Kirkendall voids. At the beginning of the reaction, molten $\mathrm{Sn}$ reacted with $\mathrm{Cu}$ to form $\mathrm{Cu}_{6} \mathrm{Sn}_{5}$, and $\mathrm{Cu}_{3} \mathrm{Sn}$ successively formed between the $\mathrm{Cu}_{6} \mathrm{Sn}_{5}$ and the $\mathrm{Cu}$. Many voids formed in the $\mathrm{Cu}_{3} \mathrm{Sn}$ phase, especially close to the $\mathrm{Cu}{ }_{3} \mathrm{Sn} / \mathrm{Cu}$ interface. When $\mathrm{Zn}$ was added in the faying surfaces, $\mathrm{Zn}$ was segregated near the interface of $\mathrm{Cu} / \mathrm{Cu}_{3} \mathrm{Sn}$ and the grain boundaries of $\mathrm{Cu}_{3} \mathrm{Sn}$. The $\mathrm{Zn}$ segregation inhibited diffusion of $\mathrm{Cu}$ due to the effect of solute drag, which also delayed growth of the $\mathrm{Cu}_{3} \mathrm{Sn}$ layer. As a result, the fluxes of $\mathrm{Cu}$ and $\mathrm{Sn}$ via the $\mathrm{Cu}_{3} \mathrm{Sn}$ phase were balanced out, which reduced the Kirkendall void formation. [doi:10.2320/matertrans.MD201509]
\end{abstract}

(Received December 5, 2015; Accepted February 2, 2016; Published March 18, 2016)

Keywords: Micro-joining, Diffusion bonding, Interdiffusion, Intermetallic compound, Kirkendall void, Zinc

\section{Introduction}

Power devices are widely used as key technologies for power and railway systems. These power devices rely on bonds such as chip/Cu substrate (die bonding) and wire-lead/ chip bonds, which have historically used Sn-based lead-free solders.

$\mathrm{SiC}$ and $\mathrm{GaN}$ are expected to be used as next-generation power semiconductors because they exhibit better efficiency and can operate at higher temperatures than Si chips. With junction temperatures approaching $473 \mathrm{~K}$ with $\mathrm{SiC}$ and GaN semiconductors, standard Sn-based lead-free solders cannot be applied for die bonding. To address the problems associated with the use of standard Sn-based lead-free solders at higher temperatures, solid-liquid interdiffusion bonding is a possible alternative for the die bonding process. In solid-liquid interdiffusion bonding, metals with low melting points such as Sn and In are sandwiched between copper bases and heated above the melting point of the inserted materials to realize die bonding by solid-liquid reaction diffusion. ${ }^{1-6)}$ The liquid phase then reacts with the base copper to form a bond layer of intermetallic compounds (IMCs) that exhibits a higher melting point than the melting point of the inserted material.

In solid-liquid interdiffusion bonding in a $\mathrm{Cu}-\mathrm{Sn}$ system, the final bond layer is composed of $\mathrm{Cu}_{3} \mathrm{Sn}$. However, voids are frequently observed near the $\mathrm{Cu}_{3} \mathrm{Sn} / \mathrm{Cu}$ interface and at the interface between the Sn-based solder and the $\mathrm{Cu}$ substrate. When the molten Sn-based solder alloy wets the copper, $\mathrm{Cu}_{6} \mathrm{Sn}_{5}$ and $\mathrm{Cu}_{3} \mathrm{Sn}$ IMCs form at the solder/Cu interface. In most cases, voids also form at the $\mathrm{Cu}_{3} \mathrm{Sn} / \mathrm{Cu}$ interface and/ or in $\mathrm{Cu}_{3} \mathrm{Sn}^{7-9)}$ Both the growth of IMCs and void formation affect the solder joint reliability, which can degrade the mechanical and electrical properties of the joints. It has been reported that the mechanism of void formation in the $\mathrm{Cu} / \mathrm{Sn}$ system is basically caused by unbalanced diffusion fluxes $\left(\mathrm{Cu}_{\text {flux }}>\mathrm{Sn}_{\text {flux }}\right)$ in the $\mathrm{Cu}_{3} \mathrm{Sn}$ phase, that is to say, the Kirkendall effect. ${ }^{10)}$ Since Kirkendall voids are formed due to unbalanced diffusion fluxes, tiny amounts of additive elements will affect void formation and the growth of IMCs. Thus, the ef- fects of various kinds of additive elements on the growth behavior of IMCs have been reported. For example, the addition of $\mathrm{Ni}$ was reported to reduce the growth of the $\mathrm{Cu}_{3} \mathrm{Sn}$ layer. ${ }^{11,12)} \mathrm{Ma}$ et al. reported that the addition of 0.05 mass $\%$ of La also reduced the growth of $\mathrm{Cu}_{6} \mathrm{Sn}_{5}{ }^{13)}$ Above all, the addition of a small amount of $\mathrm{Zn}$ is significantly effective for suppressing the growth of $\mathrm{Cu}_{6} \mathrm{Sn}_{5}$ and $\mathrm{Cu}_{3} \mathrm{Sn}$ and the formation of voids in the soldering process using Sn-based solders. ${ }^{14,15)}$ The growth of IMCs and the formation of voids were also suppressed between the $\mathrm{Sn}-\mathrm{Ag}$ solder and the $\mathrm{Cu}-\mathrm{Zn}$ alloy substrate due to the segregation of $\mathrm{Zn}$ at the $\mathrm{Cu}_{6} \mathrm{Sn}_{5} / \mathrm{CuZn}$ interface. $^{16)}$

In the present study, a small amount of $\mathrm{Zn}$ was added to the faying surface in the solid-liquid interdiffusion bonding of $\mathrm{Cu}$ using a Sn thin-film filler metal to reduce void formation. Metallurgical examination was carried out to investigate the effect of $\mathrm{Zn}$ on the solid-liquid interdiffusion bonding.

\section{Experimental procedures}

The materials used were oxygen-free $\mathrm{Cu}$ rods $3 \mathrm{~mm}$ and $5 \mathrm{~mm}$ in diameter whose faying surfaces were polished with \#4000-grit emery paper. They were then pickled in a $5 \% \mathrm{HCl}$ solution and rinsed in ethanol. The designs of the faying interfaces and the bonding setup are shown in Table 1 and Fig. 1. The faying surface of $\mathrm{Cu}$ was coated with $\mathrm{Sn}, \mathrm{Cu}$, and/ or $\mathrm{Zn}$ in order by vapor deposition in accordance with Table 1 by resistance heating under an atmosphere of $5 \times 10^{-3} \mathrm{~Pa}$. The faying surface of Design-A had only a $4-\mu$ m-thick $\mathrm{Sn}$

Table 1 Designs of faying interfaces produced by vapor deposition coating.

\begin{tabular}{lcccc}
\hline & \multicolumn{4}{c}{ Thickness $(\mu \mathrm{m})$} \\
\hline & $\mathrm{Sn}$ & $\mathrm{Cu}$ & $\mathrm{Zn}$ & $\mathrm{Sn}$ \\
\hline Design-A & 4 & - & - & - \\
\hline Design-B1 & 2 & 0.38 & - & 2 \\
Design-B2 & 2 & 0.63 & - & 2 \\
\hline Design-C1 & 2 & 0.38 & 0.02 & 2 \\
Design-C2 & 2 & 0.63 & 0.02 & 2 \\
\hline
\end{tabular}




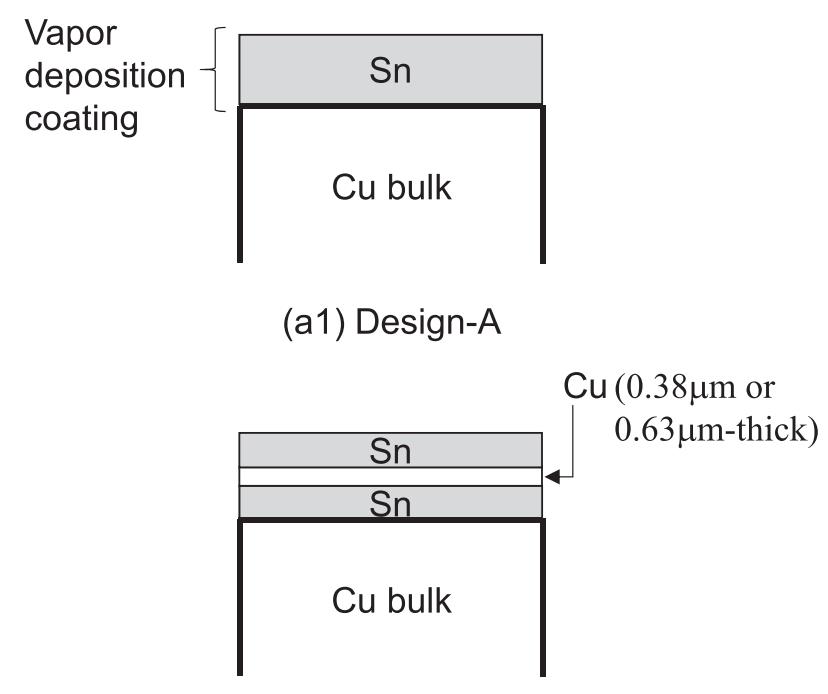

(a2) Design-B

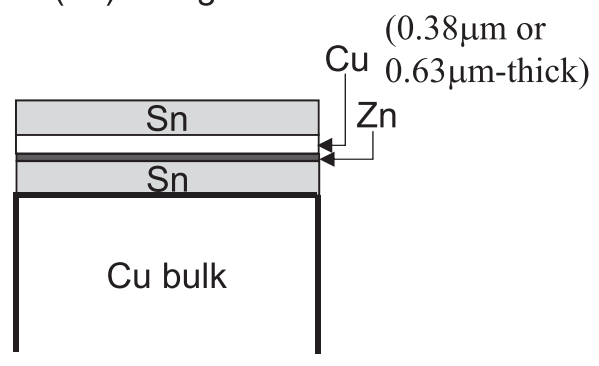

(a3) Design-C

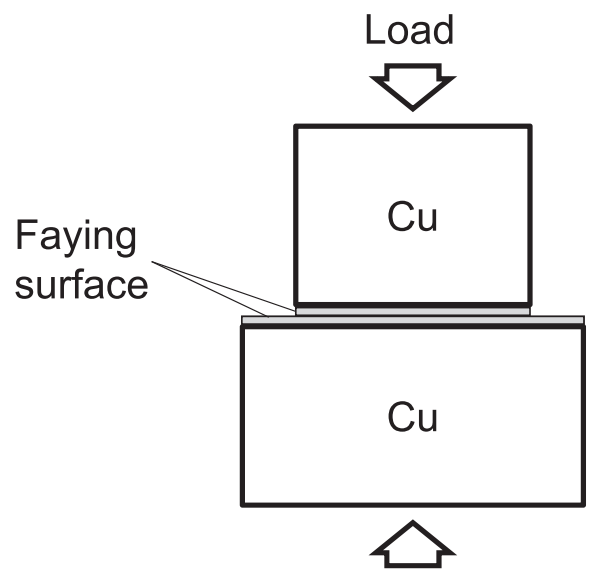

(b) Bonding setup

Fig. 1 (a1)-(a3) Designed faying surfaces prepared by vapor deposition coating and (b) set-up of solid-liquid diffusion bonding of copper. Details of the layered structures are shown in Table 1.

layer. A Cu thin film was deposited between the Sn films as an intermediate layer to fabricate a $\mathrm{Sn} / \mathrm{Cu} / \mathrm{Sn}$ faying surface, that is, Design-B. The thicknesses of the intermediate $\mathrm{Cu}$ layers in Design-B were $0.38 \mu \mathrm{m}$ and $0.63 \mu \mathrm{m}$, denoted as Design-B1 and B2, respectively. Similarly, a $0.02-\mu \mathrm{m}$-thick Zn layer was deposited between the $\mathrm{Sn}$ and $\mathrm{Cu}$ layers on the Design-B1 and B2 faying surfaces, denoted as Design-C1 and
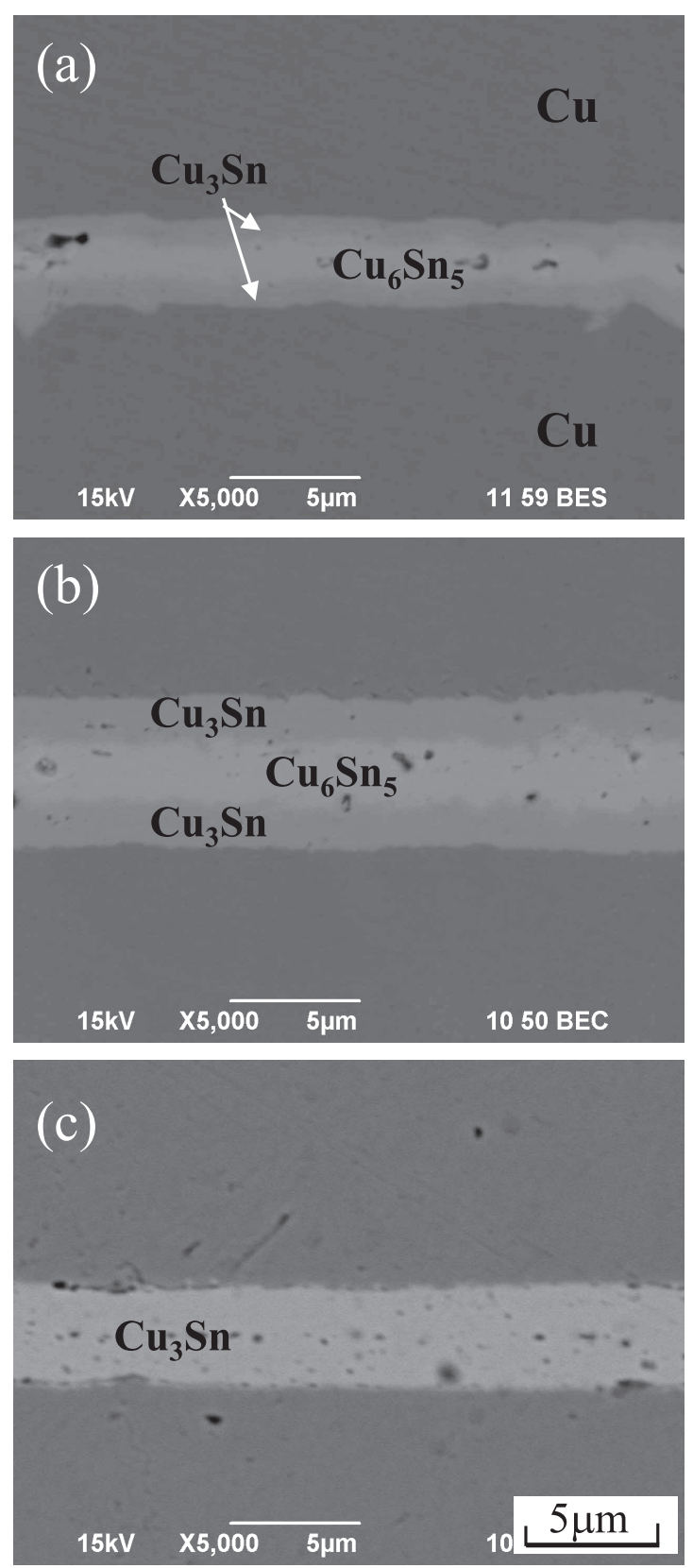

Fig. 2 Growth of IMC bond layers using deposited Sn coating (Design-A) at bonding times of (a) 300, (b) 600, and (c)1800 s. Bonding temperature is $573 \mathrm{~K}$.

C2 faying surfaces, respectively. The bonding between the $\phi 3 \mathrm{~mm}$ and $\phi 5 \mathrm{~mm} \mathrm{Cu}$ specimens was performed at $573 \mathrm{~K}$ for bond times of 300,600, and $1800 \mathrm{~s}$ under a bonding pressure of $10 \mathrm{MPa}$ in nitrogen gas flow atmosphere $(2 \mathrm{~L} / \mathrm{min})$, as shown in Fig. 1b. The microstructures of the bond layers were observed by scanning electron microscopy (SEM) and transmission electron microscopy (TEM) with energy dispersive $\mathrm{X}$-ray spectroscopy (EDX). The specimens for TEM observation were prepared by the focused ion beam (FIB) method.

\section{Results and discussion}

\subsection{Bonding using mono-Sn film}

The copper was bonded to itself using a mono-Sn film, that is, the Design-A faying surface, at $573 \mathrm{~K}$. The cross sections 

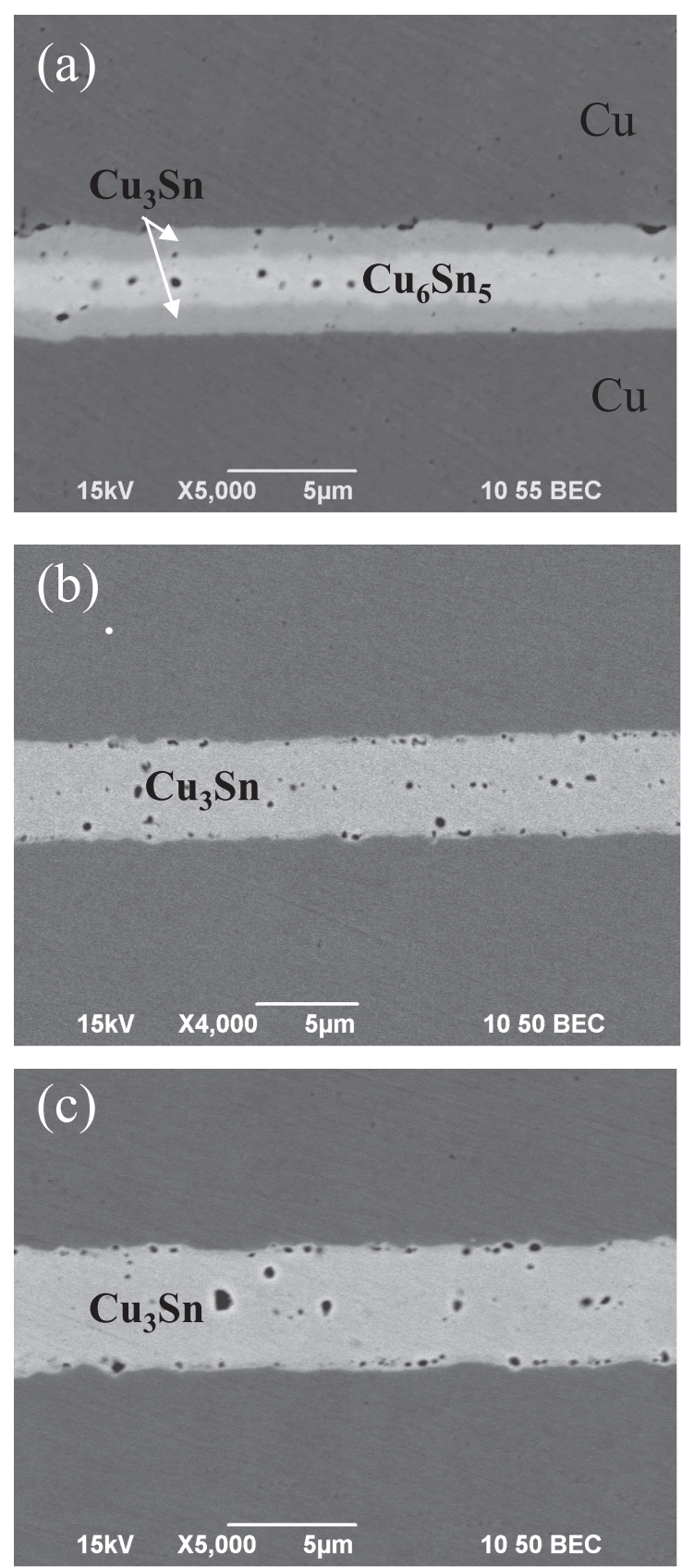
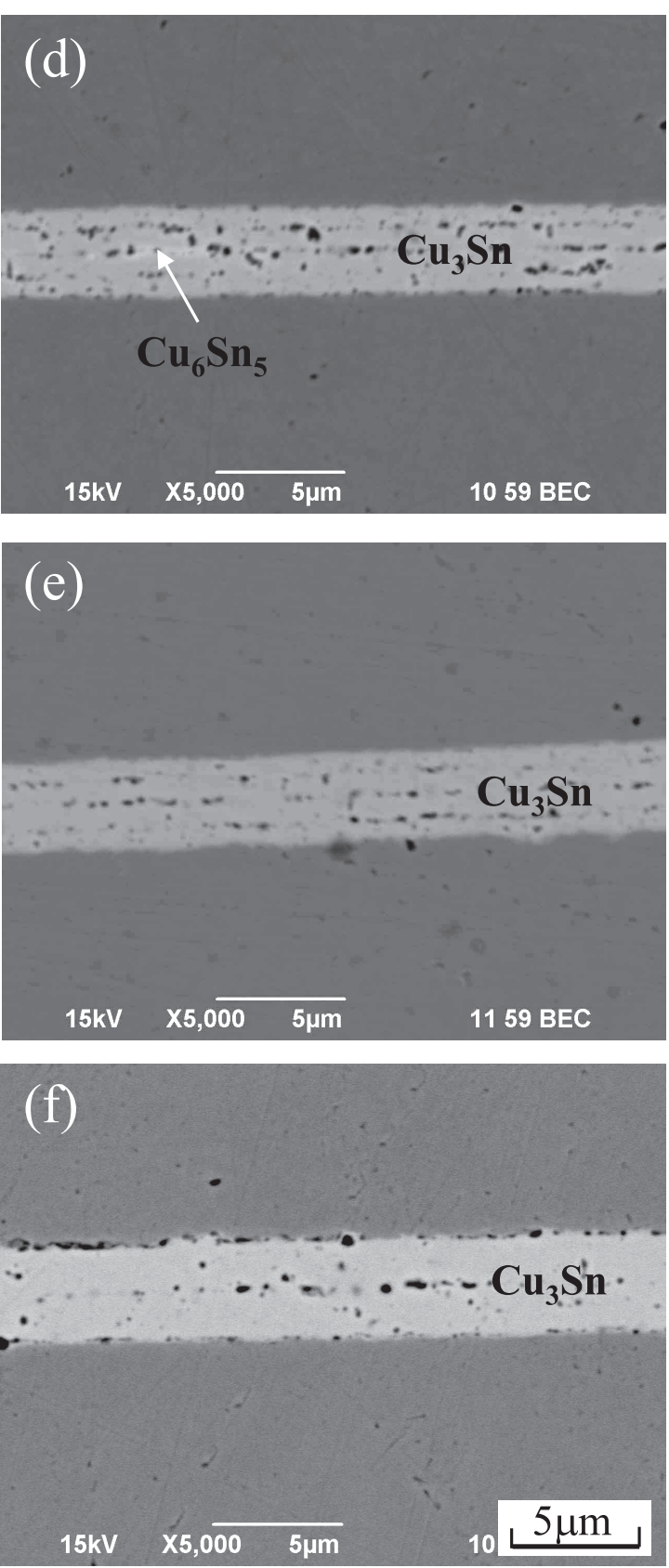

Fig. 3 Growth of IMC bond layers using deposited $\mathrm{Sn} / \mathrm{Cu} / \mathrm{Sn}$ coatings (Design-B faying surfaces) as a function of bond times of (a) 300, (b) 600, and (c) $1800 \mathrm{~s}$ for the Design-B1 faying surface and of (d) 300, (e) 600, and (f) $1800 \mathrm{~s}$ for the Design-B2 faying surface. Bonding temperature is $573 \mathrm{~K}$.

of the bonded layers are shown in Fig. 2. When the temperature reaches $505 \mathrm{~K}$, Sn melts, which improves the adhesion between the two materials. Once a liquid phase formed, $\mathrm{Cu}$ dissolved into the liquid $\mathrm{Sn}$, resulting in the formation of $\mathrm{Cu}_{6} \mathrm{Sn}_{5}$. Subsequently, $\mathrm{Cu}_{3} \mathrm{Sn}$ formed at the interface between $\mathrm{Cu}_{6} \mathrm{Sn}_{5}$ and $\mathrm{Cu}$ due to reaction diffusion during the heating process up to $573 \mathrm{~K}$ (Fig. 2a). Because the amount of liquid $\mathrm{Sn}$ was quite small, it was consumed completely to form $\mathrm{Cu}-$ $\mathrm{Sn}$ IMCs immediately. The thickness of the $\mathrm{Cu}_{3} \mathrm{Sn}$ layer increased with decreasing $\mathrm{Cu}_{6} \mathrm{Sn}_{5}$ thickness during the holding process at $573 \mathrm{~K}$, until the whole bond layer was occupied by $\mathrm{Cu}_{3} \mathrm{Sn}$ (Fig. 2c). It is worth noting that many voids appeared in the bond layer and at the interface of $\mathrm{Cu}_{3} \mathrm{Sn} / \mathrm{Cu}$ as the thickness of the $\mathrm{Cu}_{3} \mathrm{Sn}$ layer increased. In a $\mathrm{Cu}_{3} \mathrm{Sn}$ phase, diffusion rate of $\mathrm{Cu}$ is faster than that of $\mathrm{Sn}$ as a result of the so-called "ordered $\mathrm{Cu}_{3} \mathrm{Au}$ rule." In general, in compounds of the form $\mathrm{A}_{m} \mathrm{~B}_{n}$, where $m / n$ is greater than 2, the atoms of species A diffuse considerably faster than those of species B. d'Heurle et al. explained the phenomenon by the fact that, in general, the majority atoms constitute a continuous network in which a vacancy can easily migrate. On the other hand, the motion of minority atoms requires either the coexistence of two vacancies (minority and majority) or a local destruction of the crystalline lattice. ${ }^{17,18)}$ Therefore, the majority atoms of $\mathrm{Cu}$ are more mobile than the minority atoms of $\mathrm{Sn}$ in $\mathrm{Cu}_{3} \mathrm{Sn}$. In the present study, $\mathrm{Cu}_{3} \mathrm{Sn}$ grew between $\mathrm{Cu}$ and $\mathrm{Cu}_{6} \mathrm{Sn}_{5}$ due to solid-phase reaction diffusion. Thus, most of these voids are believed to be Kirkendall voids. 

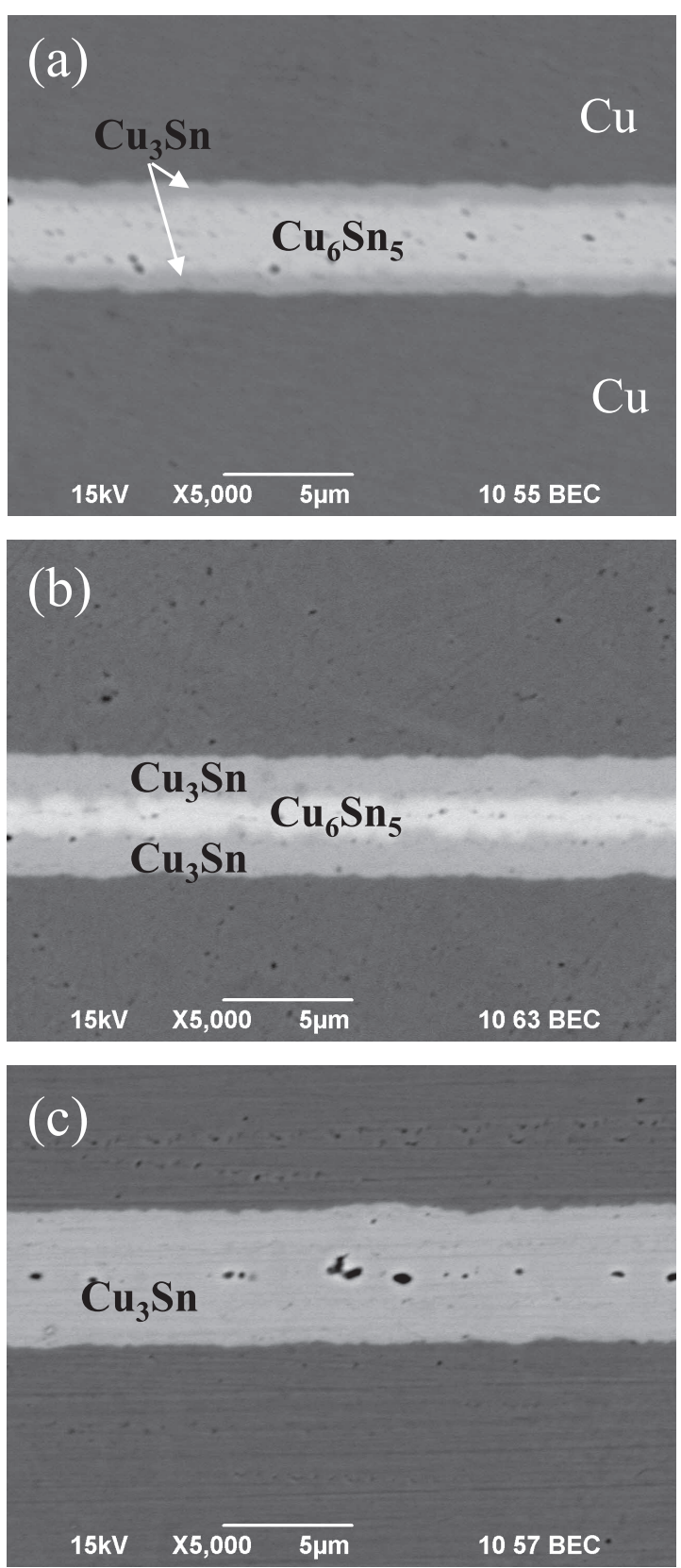
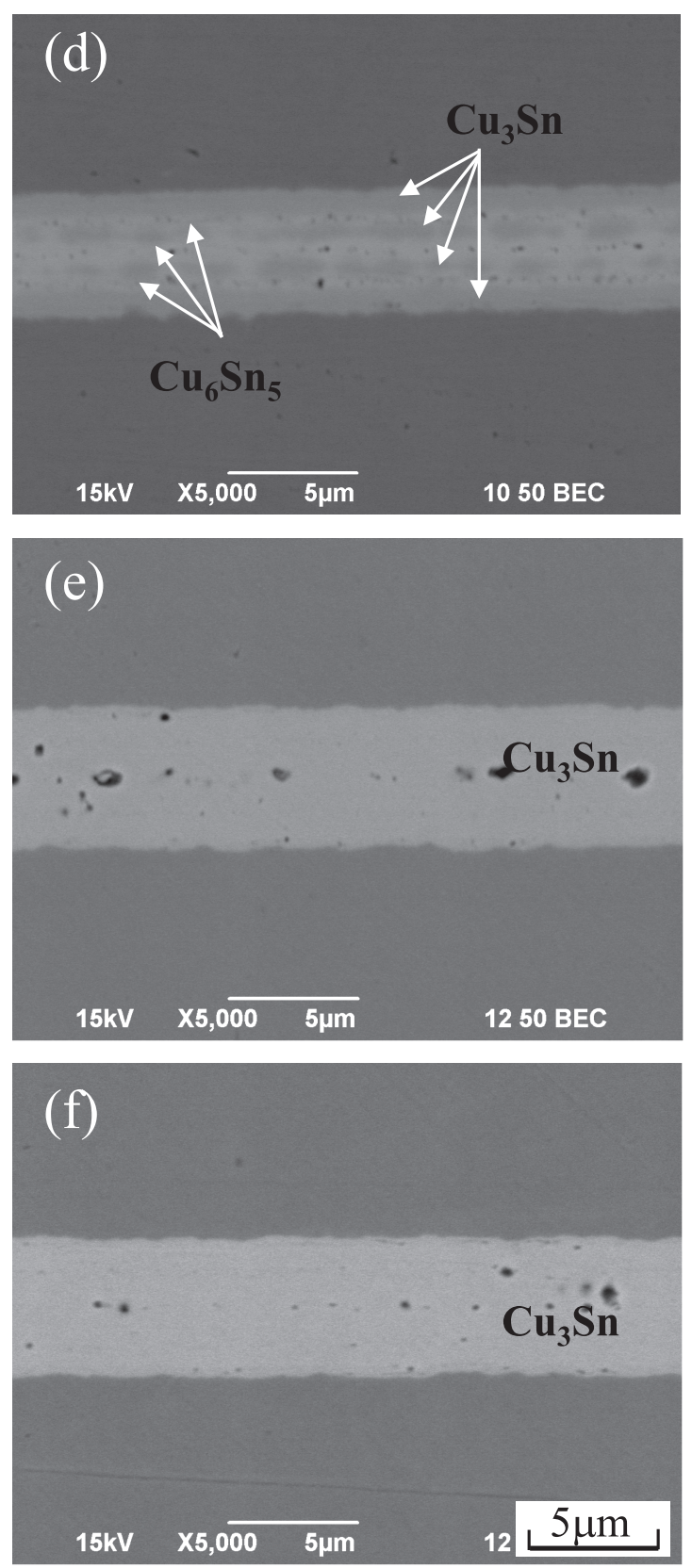

Fig. 4 Effect of $\mathrm{Zn}$ addition on IMC growth as a function of bond times of (a) 300, (b) 600, and (c) $1800 \mathrm{~s}$ for the Design-C1 faying surface and of (d) 300 , (e) 600 , and (f) $1800 \mathrm{~s}$ for the Design-C2 faying surface. Bonding temperature is $573 \mathrm{~K}$.

\subsection{Bonding using $\mathrm{Cu} / \mathrm{Sn}$ films}

In the case of a mono-Sn film, $\mathrm{Cu}$ atoms were supplied from only $\mathrm{Cu}$ base metals to form $\mathrm{Cu}_{3} \mathrm{Sn}$. Then, a Cu thin film was supplied between the two Sn thin films of the faying surface (Fig. 1, Design-B) to shorten the apparent reaction time to form a $\mathrm{Cu}_{3} \mathrm{Sn}$ layer. These $\mathrm{Cu}$ films are expected to work as another source of $\mathrm{Cu}$ to form $\mathrm{Cu}_{3} \mathrm{Sn}$. Figure 3 shows the cross sections of the bond interfaces of $\mathrm{Cu}$ bonded using Design-B1 and Design-B2 faying surfaces at $573 \mathrm{~K}$ with bond times of 300,600 , and $1800 \mathrm{~s} . \mathrm{Cu}_{6} \mathrm{Sn}_{5}$ disappeared at the bond time of $600 \mathrm{~s}$ when using both Design-B1 and Design-B2 faying surfaces. Even at $300 \mathrm{~s}$ of bond time, most of the bond layer was composed of $\mathrm{Cu}_{3} \mathrm{Sn}$ as a result of the increasing thickness of the intermediate $\mathrm{Cu}$ film (Fig. 3d). By locating a thin $\mathrm{Cu}$ film in the deposited layer as an intermediate supply source, the transformation from $\mathrm{Cu}_{6} \mathrm{Sn}_{5}$ to $\mathrm{Cu}_{3} \mathrm{Sn}$ was completed in a shorter time than in the case of bonding using only the mono-Sn film as the faying surface. However, the unbalanced diffusion flux between $\mathrm{Sn}$ and $\mathrm{Cu}$ in the $\mathrm{Cu}_{3} \mathrm{Sn}$ phase has not been solved, and the addition of a $\mathrm{Cu}$ film into the $\mathrm{Sn}$ films increased the number of $\mathrm{Cu} / \mathrm{Sn}$ interfaces. As a result, many more Kirkendall voids formed in the resulting bond layer than occurred using the mono-Sn film.

\subsection{Effect of zinc}

The addition of a deposited $\mathrm{Cu}$ film into the deposited $\mathrm{Sn}$ film shortened the apparent bond time; however, it increased the number of Kirkendall voids. Zn was therefore deposited between the deposited $\mathrm{Cu} / \mathrm{Sn}$ films. Figure 4 shows the cross sections of the bond interfaces of $\mathrm{Cu}$ bonded using the Design-C1 and Design-C2 faying surfaces at $573 \mathrm{~K}$ with bond times of 300, 600, and $1800 \mathrm{~s}$. The microstructure of the bond 


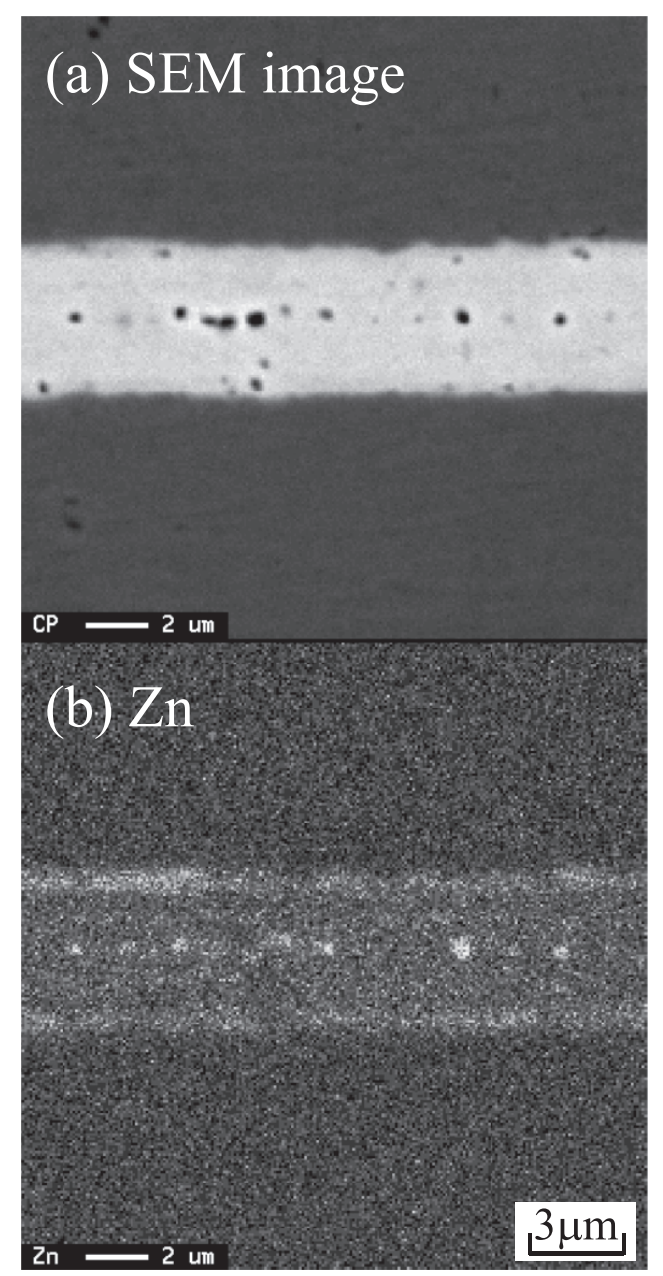

Fig. 5 (a) SEM image and (b) $\mathrm{Zn}$ mapping of the distribution of $\mathrm{Zn}$ in the bond interface bonded for $1800 \mathrm{~s}$ using the Design-C1 faying surface. Bonding temperature is $573 \mathrm{~K}$.

layer composed of $\mathrm{Cu}_{3} \mathrm{Sn}$ and $\mathrm{Cu}_{6} \mathrm{Sn}_{5}$ was similar to that of the bond layer without $\mathrm{Zn}$. However, the number of Kirkendall voids drastically decreased by the addition of $\mathrm{Zn}$. On the other hand, it took longer for the whole bond layer to show only a $\mathrm{Cu}_{3} \mathrm{Sn}$ phase than was the case with bonding without $\mathrm{Zn}$. When $\mathrm{Zn}$ was added in the faying surface of Design-B1, $\mathrm{Cu}_{6} \mathrm{Sn}_{5}$ remained in the bond layer even at the bond time of $600 \mathrm{~s}$ (see Fig. 4b). In a similar fashion, $\mathrm{Cu}_{6} \mathrm{Sn}_{5}$ layers were obviously observed in the bond layer for the bond time of $300 \mathrm{~s}$ when $\mathrm{Zn}$ was added in the faying surface of Design-B2 (see Fig. 4d).

The distribution of $\mathrm{Zn}$ was investigated by SEM with EDX analysis. Figure 5 shows the $\mathrm{Zn}$ distribution in the bond layer using the faying surface with the addition of $\mathrm{Zn}$. Zn was mainly segregated at the interface between the bond layer and the base metal, and some $\mathrm{Zn}$ remained around the voids located at the center of the bond layer. These voids were not Kirkendall voids since they were relatively-large compared with the voids that were formed at the $\mathrm{Cu}$ /bond layer interface. They were probably formed when the final liquid phase were solidified isothermally at the center of bond layer. The detailed microstructures of the bond layers with a bond time of $300 \mathrm{~s}$ were observed using TEM with EDX analyses (Fig. 6 and Fig. 7). Table 2 shows the results of quantitative EDX
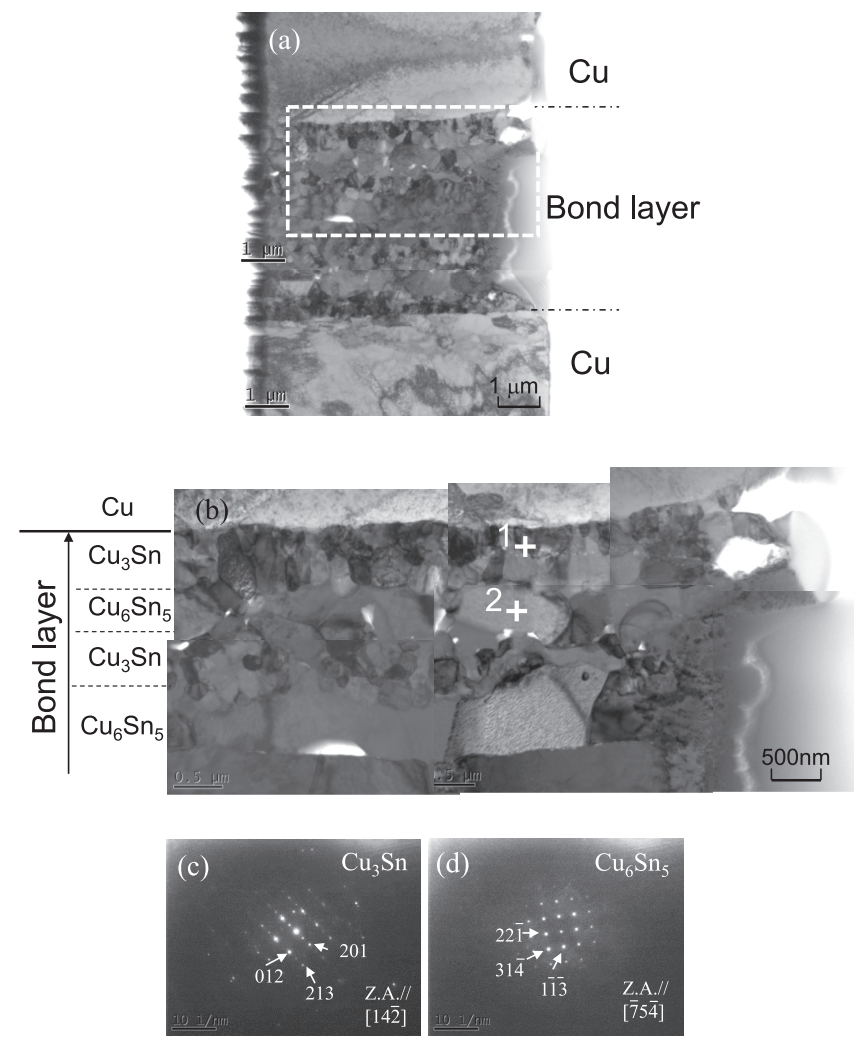

Fig. 6 TEM observation of IMC layer bonded for $300 \mathrm{~s}$ with the Design-C1 faying surface. (a) Bright-field image of IMC layer, (b) highlighted area in (a), (c) SADP from point 1, and (d) SADP from point 2. Bonding temperature is $573 \mathrm{~K}$.

analysis at each point shown in Fig. 7a. The beam diameter used for EDX analysis was $\sim 2 \mathrm{~nm}$. TEM observation revealed that the bond layer was composed of $\mathrm{Cu}_{6} \mathrm{Sn}_{5} / \mathrm{Cu}_{3} \mathrm{Sn}$ layered microstructure, and the grain size of $\mathrm{Cu}_{3} \mathrm{Sn}$ was finer than that of $\mathrm{Cu}_{6} \mathrm{Sn}_{5}$. Such obvious layered structure were not observed by SEM as shown in Fig. 4a. Because the layered structure is transition state, and the thickness of vapor deposition coating was not controlled perfectly. Therefore, some degree of variability on microstructures could occur even at the same bonding condition. Analysis points Nos. 1-5 in Fig. 7 correspond to $\mathrm{Cu}_{3} \mathrm{Sn}$ and No. 6 corresponds to $\mathrm{Cu}_{6} \mathrm{Sn}_{5}$. The EDX points and line analyses revealed that $\mathrm{Zn}$ was segregated at the interface between $\mathrm{Cu}_{3} \mathrm{Sn}$ and the $\mathrm{Cu}$ base metal and at the grain boundary of $\mathrm{Cu}_{3} \mathrm{Sn}$.

Figure 8 shows the TEM bright-field images and selected area diffraction patterns (SADPs) of the IMC layer bonded for $1800 \mathrm{~s}$. When the bond time reached $1800 \mathrm{~s}$, most of the bond layer was composed of coarse grains, and there were fine grains near the interface between the bond layer and the $\mathrm{Cu}$ base metal. $\mathrm{Cu}_{6} \mathrm{Sn}_{5}$ completely disappeared in the bond layer. It is particularly worth noting that $\mathrm{Cu}_{3} \mathrm{Sn}$ with fine grains formed next to the interface between the bond layer and the $\mathrm{Cu}$ base metal. As shown in Fig. 5, the fine grain area corresponds to where $\mathrm{Zn}$ was segregated. The grain boundary segregation of the solute inhibits the mobility of the grain boundary, that is to say, solute drag, which delays the grain growth of $\mathrm{Cu}_{3} \mathrm{Sn}$ next to the $\mathrm{Cu}$ base metal. The interfacial and grain boundary segregation of $\mathrm{Zn}$ also inhibits diffusion of $\mathrm{Cu}$ in $\mathrm{Cu}_{3} \mathrm{Sn}$. The atoms of $\mathrm{Sn}$ are also affected by the seg- 

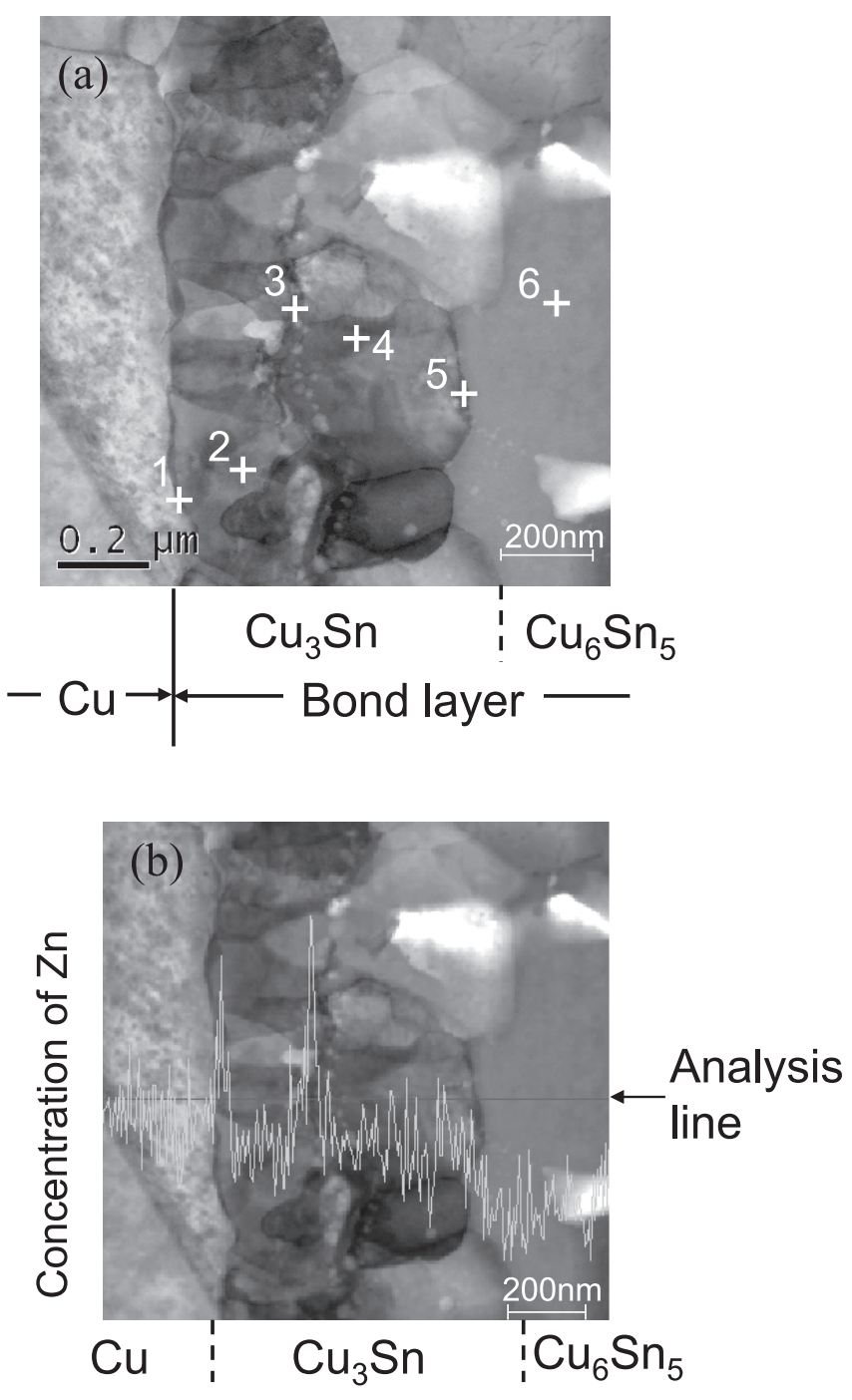

Fig. 7 (a) TEM bright-field image and (b) EDX analysis of $\mathrm{Zn}$ near $\mathrm{Cu} /$ $\mathrm{Cu}_{3} \mathrm{Sn}$ bond interface. The bonding was carried out for $300 \mathrm{~s}$ using the Design-C1 faying surface. The compositions at each point in (a) are shown in Table 2. Bonding temperature is $573 \mathrm{~K}$.

Table 2 Results of quantitative EDX analysis at each point shown in Fig. 7.

\begin{tabular}{cccc}
\hline \multirow{2}{*}{ Point } & \multicolumn{3}{c}{ Composition (at\%) } \\
\cline { 2 - 4 } & $\mathrm{Cu}$ & $\mathrm{Sn}$ & $\mathrm{Zn}$ \\
\hline 1 & 92.9 & 5.2 & 1.9 \\
2 & 75.7 & 24.0 & 0.3 \\
3 & 72.2 & 23.4 & 4.4 \\
4 & 74.5 & 35.4 & 0.1 \\
5 & 69.5 & 30.1 & 0.4 \\
6 & 54.7 & 45.1 & 0.2 \\
\hline
\end{tabular}

regation of $\mathrm{Zn}$. However, because $\mathrm{Sn}$ is the minor atom for diffusion, as mentioned above, the effect of $\mathrm{Zn}$ segregation on the mobility of $\mathrm{Sn}$ in the $\mathrm{Cu}_{3} \mathrm{Sn}$ phase might be limited. As a result, the formation of Kirkendall voids is inhibited by the addition of $\mathrm{Zn}$.

\section{Conclusions}

Copper was bonded to itself by using a deposited $\mathrm{Sn}$ film
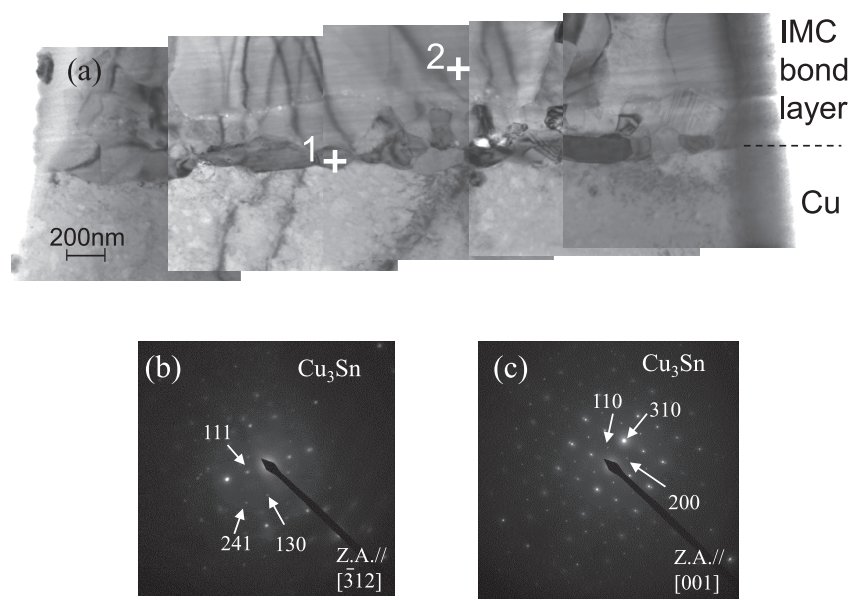

Fig. 8 TEM observation of IMC layer bonded for $1800 \mathrm{~s}$ with the Design-C1 faying surface. (a) Bright-field image, (b) SADP from point 1 , and (c) SADP from point 2. Bonding temperature is $573 \mathrm{~K}$.

including $\mathrm{Cu}$ and/or $\mathrm{Zn}$. The effect of $\mathrm{Zn}$ addition on the growth rate of the intermetallic compounds and the formation of Kirkendall voids was investigated. The following results were obtained:

(1) When $\mathrm{Cu}$ was bonded at $573 \mathrm{~K}$ using the faying surface of the deposited Sn film, liquid Sn immediately reacted with $\mathrm{Cu}$ to form $\mathrm{Cu}_{6} \mathrm{Sn}_{5}$. $\mathrm{Cu}_{3} \mathrm{Sn}$ formed successively between $\mathrm{Cu}_{6} \mathrm{Sn}_{5}$ and $\mathrm{Cu}$, and the thickness of the $\mathrm{Cu}_{3} \mathrm{Sn}$ layer increased with increasing bond time. Many voids formed near the interface between $\mathrm{Cu}_{3} \mathrm{Sn}$ and the $\mathrm{Cu}$ base metal with increasing thickness of the $\mathrm{Cu}_{3} \mathrm{Sn}$ phase. Finally, the bond layer consisted of only single-phase $\mathrm{Cu}_{3} \mathrm{Sn}$.

(2) The time needed to form single-phase $\mathrm{Cu}_{3} \mathrm{Sn}$ in the bond layer was shortened by using $\mathrm{Sn} / \mathrm{Cu} / \mathrm{Sn}$ multilayered films. A thin $\mathrm{Cu}$ layer on the faying surface worked as an intermediate supply source to form $\mathrm{Cu}_{3} \mathrm{Sn}$. On the other hand, the number of Kirkendall voids increased at the $\mathrm{Cu} / \mathrm{Cu}_{3} \mathrm{Sn}$ interface in the bond layer.

(3) The number of Kirkendall voids decreased by the addition of a small amount of $\mathrm{Zn}$ in the faying surface. The segregation of $\mathrm{Zn}$ at the $\mathrm{Cu}_{3} \mathrm{Sn} / \mathrm{Cu}$ interface and $\mathrm{Cu}_{3} \mathrm{Sn}$ grain boundaries inhibited the mobility of $\mathrm{Cu}$. On the other hand, the addition of $\mathrm{Zn}$ reduced the growth rate of the $\mathrm{Cu}_{3} \mathrm{Sn}$ layer.

\section{Acknowledgements}

The authors gratefully thank Dr. Makoto Takahashi for his experimental support. This work was partially supported by JSPS KAKENHI Grand Numbers 24560883, 25289242, and the New Energy and Industrial Technology Development Organization (NEDO).

\section{REFERENCES}

1) T. Fujimoto, S. Fukumoto, T. Miyazaki, Y. Kashiba, K. Shiotani and K. Fujimoto: J. Phys. Conf. Ser. 379 (2012) 012026.

2) J.F. Li, P.A. Agyakwa and C.M. Johnson: Acta Mater. 59 (2011) 11981211.

3) S. Bader, W. Gust and H. Hieber: Acta Metall. Mater. 43 (1995) 329337.

4) C.C. Lee and Y.-C. Chen: Thin Solid Films 286 (1996) 213-218.

5) S. Fukumoto, K. Miyake, S. Tatara, M. Matsushima and K. Fujimoto: 
Mater. Trans. 56 (2015) 1019-1024.

6) P.J. Wang, J.S. Kim and C.C. Lee: J. Electron. Mater. 38 (2009) 21062111.

7) W. Yang, R.W. Messler, Jr. and L.E. Felton: J. Electron. Mater. 23 (1994) 765-772.

8) J.Y. Kim and Jin Yu: Appl. Phys. Lett. 92 (2008) 092109.

9) T.S. Huang, H.W. Tseng, Y.H. Hsiao, C.H. Cheng, C.T. Lu and C.Y. Liu: Electrochem. Solid-State Lett. 14 (2011) H393-H396.

10) M.Y. Tsai, S.C. Yang, Y.W. Wang and C.R. Kao: J. Alloy. Compd. 494 (2010) 123-127.

11) T. Laurila, J. Hurtig, V. Vuorine and J.K. Kivilahti: Microelectron. Re- liab. 49 (2009) 242-247.

12) V. Vuorinen, T. Laurila, T. Mattila, E. Heikinheimo and J.K. Kivilahti: J. Electron. Mater. 36 (2007) 1355-1362.

13) X. Ma, Y. Qian and F. Yoshida: J. Alloy. Compd. 334 (2002) 224-227.

14) C.-Y. Yu and J.-G. Duh: Scr. Mater. 65 (2011) 783-786.

15) J.Y. Kim, J. Yu and S.H. Kim: Acta Mater. 57 (2009) 5001-5012.

16) H.F. Zou, Q.K. Zhang and Z.F. Zhang: J. Electron. Mater. 40 (2011) 1542-1548.

17) F.M. d'Heurle and P. Gas: J. Mater. Res. 1 (1986) 205-221.

18) F.M. d'Heurle, P. Gas, C. Lavoie and J. Philibert: Z. Metallk. 95 (2004) 852-859. 